FACULTY OF ECONOMICS AND APPLIED ECONOMIC SCIENCES

CENTER FOR ECONOMIC STUDIES

ENERGY, TRANSPORT \& ENVIRONMENT

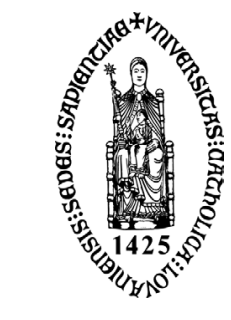

KATHOLIEKE UNIVERSITEIT

LEUVEN

WORKING PAPER SERIES

$n^{\circ}$ 2003-11

\title{
MARGINAL SOCIAL COST PRICING FOR ALL TRANSPORT MODES AND THE EFFECTS OF MODAL BUDGET CONSTRAINTS
}

\author{
S. Proost (K.U.Leuven) \\ K. Van Dender (University of California at Irvine)
}

October 2003

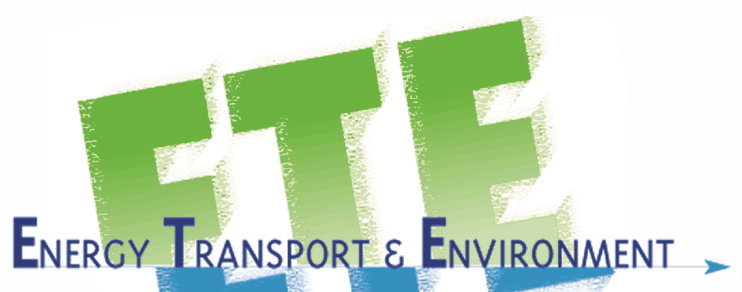

secretariat:

Isabelle Benoit

KULeuven-CES

Naamsestraat 69, B-3000 Leuven (Belgium)

tel: $\quad+32(0) 1632.66 .33$

fax: $\quad+32(0) 1632.69 .10$

e-mail: Isabelle.Benoit@econ.kuleuven.ac.be

http://www.kuleuven.be/ete 


\title{
Marginal Social Cost Pricing for all Transport modes
}

\author{
and the effects of modal budget constraints
}

Stef Proost and Kurt Van Dender ${ }^{1}$

\begin{abstract}
This paper studies the order of magnitude of the pricing corrections that are needed to implement marginal social cost pricing for all transport modes. With the TRENEN model we study this question for 6 areas in the EU. As marginal social cost pricing may generate important surpluses and deficits for the different modes, we also study the effects of two alternative pricing rules that satisfy budget constraints. We examine the effects of average cost pricing that guarantees a budget balance per mode. The second alternative pricing rule we study is social Ramsey pricing (or marginal social cost pricing with a budget constraint) where we impose a budget constraint at the level of the transport sector. We estimate transport effects and welfare effects of the three pricing rules. We show that average pricing rules may actually do worse than the present pricing rules and that social Ramsey pricing may achieve $50 \%$ or more of the maximal welfare gain.
\end{abstract}

\section{Keywords}

Transport pricing, optimal taxes, externalities, transport budget constraints

\footnotetext{
${ }^{1}$ Stef Proost, Center for Economic Studies, KULeuven, and Kurt Van Dender, University of California at Irvine
} 


\section{INTRODUCTION}

This paper studies the effects of more efficient pricing in the transport sector. The introduction of road pricing is a central component of social marginal cost pricing, but it is not the only one, as other modes, like rail and urban public transport, need important pricing corrections as well. ${ }^{2}$ Correcting the prices on one market and not others may decrease the overall welfare gain, or even decrease welfare.

The first objective of this paper is to estimate, for the transport sector as a whole, the magnitude of the required price corrections, as well as their effects on traffic flows, government revenues and welfare. Marginal social cost pricing is often considered as an exercise of academic nature with little political relevance. When proposals for substantial pricing reforms in the transport sector are discussed, one of the major counterarguments used by interest groups is the risk for unbalanced budgets between transport modes. There is a general fear that taxes on car use would indeed strongly increase, and the receipts would be used to fill the larger deficits in the public transport sectors. Car lobby groups will therefore typically require that all modes balance their budgets.

This call for budget equilibrium is motivated in several ways. First, there is the efficiency concern that prices below average costs lead to excessive use of a commodity. Second, there is the cost-efficiency concern that the absence of a rigid balanced budget requirement for a mode like rail acts like a blank check so that production operations will become less cost-efficient. Third, there is a fear of loss of

\footnotetext{
${ }^{2}$ See Glaister and Lewis (1978) for an early application of optimal pricing with several modes.
} 
transparency. Finally, there are concerns regarding unacceptable transfers between population groups.

The second objective of this chapter is to assess the effects of balanced budget requirements. More specifically, the efficiency- and transport sector effects of three alternative pricing schemes are discussed. We compare existing pricing practices with marginal social cost pricing (MSC) and with two pricing rules that guarantee a balanced budget. The first is simple average cost pricing for each mode (ACM), the second is Ramsey pricing with budget equilibrium for the whole transport sector (RMS). Both average cost pricing and Ramsey pricing are deviations from marginal social cost pricing, for which we want to gauge the extent of the revenue effects as well as the potential efficiency losses of imposing budget constraints in the transport sector. This exercise could be considered as an input into a broader analysis that uses a political economy approach (e.g. Grossman and Helpman, 2001), where issues like earmarking of tax revenues ${ }^{3}$ and efficiency incentives for the transport ministries (in the sense of Tirole, 1994) are studied.

The computations are done for a set of European cities and non-urban areas, always using the same aggregate optimal pricing model. We focus on pricing reform for given infrastructure, excluding the investment problem. Moreover, it is assumed that all transport is produced in a cost-efficient way, so that any cost-efficiency concern generated by budget balance requirements is ignored. ${ }^{4}$ Finally, income distribution concerns between population groups are ignored, as this requires a general equilibrium approach that keeps track of the use of transport revenue surpluses or deficits in other sectors of the economy (Mayeres and Proost, 1997 and 2003).

\footnotetext{
${ }^{3}$ See Newbery and Santos (1999) for a contribution on earmarking of road taxes
} 
The pricing rules considered in this chapter are defined in Section 2. The model is described briefly in Section 3. The reference equilibrium and the budget constraints are discussed in Section 4. The effects of the different pricing rules are compared in Section 5. Section 6 concludes.

\section{WHICH PRICING RULES ARE COMPARED?}

Three pricing rules are tested. As shown in Table 1 they differ in two characteristics:

(i) whether they need to balance the financial transport account or not, and (ii)

whether they use marginal social cost information or not.

\footnotetext{
${ }^{4}$ It is well known in the theory of incentives that a regulation scheme that imposes a maximum deficit can generate production efficiency (see Laffont and Tirole, 1993).
} 
Table 1: $\quad$ Transport Pricing Rules

\begin{tabular}{|l|c|c|}
\hline Balanced modal transport & \multicolumn{2}{|c|}{ Pricing principle } \\
\cline { 2 - 3 } account or financial cost & Average cost & Marginal cost \\
\hline Required by transport & Average cost pricing & \\
mode & (ACM) & Ramsey social cost pricing \\
\hline Required for transport & & (RMS) \\
sector & & Marginal social cost pricing \\
\hline Not required & & (MSC) \\
\hline
\end{tabular}


When the average cost pricing by mode (ACM) rule is used, prices are equal to the sum of financial costs of that mode divided by its total volume. This implies that no attention is paid to the structure of resource costs (fixed or not, sunk or not, etc.), no consideration of any external costs is made, and all transport services (freight, passengers etc.) within that mode are treated identically. The main goal of average cost pricing is cost recovery. There are many forms of average cost pricing because both the numerator and the denominator are to some extent arbitrary. First, several volume indicators can be used, e.g. trips or vehicle kilometer for passengers and tonkilometer or vehiclekilometer for freight. Second, accounting rules are not uniform (depreciation rules etc.) and can lead to different total cost concepts; cf. e.g. Jha (1998). We use only one of many definitions of average costs, as what matters is to show how important are cost recovery and the disregard of the resource cost and external cost structure (marginal costs by time of day etc.) for economic efficiency.

When the marginal social cost pricing (MSC) rule is used, prices are equal to the sum of the marginal resource cost (extra cost of driver time, fuel, wear and tear of vehicle, all before taxes) and the marginal external cost (including congestion, air pollution, noise, accidents and maintenance cost of the infrastructure), for a given infrastructure. With this pricing rule, the financial impact per mode is ignored.

When the Ramsey social cost pricing for the transport sector (RMS) rule is used, prices are set as optimal deviations from marginal social costs. The deviations are required to meet cost recovery targets for the transport sector as a whole. If marginal social cost pricing generates insufficient revenue to cover financial costs, RMS pricing requires that the margins (price-marginal social cost) are increased in a way that is inversely proportional to the elasticity of demand in the relevant market. More over in setting the margins, care has to be taken of the potential distortionary effects 
on other transport markets. This means that mark-ups on top of marginal social costs are differentiated between the different transport services (peak, off-peak, passengers, freight). This principle looks complicated but is well known in the theory of monopolistic pricing and is common practice in all businesses that exploit their market power (airlines, soft drinks, telecom, computers, private education, supermarkets, etc. ${ }^{5}$ ). The main difference with our application is that private firms are not concerned with external costs.

Many alternatives to the pricing rules defined above can be defined, and some may perform better than the ones discussed in this chapter. We mention two possibilities. First, one could define the Ramsey pricing principle at the level of each mode and look for optimal differentiation between different services of the same mode (e.g. return or single ticket, etc.). This looks less interesting because the budget balance in this paper is not really imposed at the modal level; the model used here is multi-modal and rather aggregated. Second, two-part tariffs may outperform Ramsey pricing. The reason why Ramsey pricing is considered instead of two-part tariffs is technical: the aggregate simulation model that is used does not allow the computation of the full benefits of two-part tariffs. A micro-simulation model based on representative samples would be needed in order to tackle that issue. ${ }^{6}$

\section{THE MODEL}

The pricing rules are assessed using TRENEN, a multi-modal partial equilibrium model. ${ }^{7}$ The model describes the market equilibrium for all surface transport markets simultaneously. It covers passengers and freight, and private and public transport

\footnotetext{
${ }^{5}$ See any intermediate micro-economics textbook, e.g. Pindyck and Rubinfeld (2001, p370-403)

${ }^{6}$ The design of optimal two-part tariffs in the presence of externalities is discussed in De Borger (2001).

${ }^{7}$ For more details on the model. see Proost and Van Dender (2001a and 2001b).
} 
modes. One of its main features is that it can optimize the pricing structure over several modes under any type of pricing constraint. There are different model versions for urban and for non-urban transport. We briefly describe the urban model version and focus on passenger transportation. Figure 1 shows the model structure.

\subsection{Assumptions}

Three important assumptions allow us to build a simple multi-modal model that can be used to compute optimal tax structures. The first assumption is that the travel conditions in the urban (non-urban) area can be represented by one aggregated speedflow relationship. ${ }^{8}$ This means that area specific and route choice features cannot be studied. The second assumption is that demand is generated by a limited number of representative consumers. The consequence is that distributional issues cannot be studied. The third assumption is that we use medium term static model. This means that the level of all transport infrastructure is taken as given, but that the car stocks and public transport equipment (number of busses and rail carriages) fully adapt to the level of demand.

\subsection{The demand for transport}

The behaviour of a representative household is derived from the maximisation of an indirect utility function defined over generalized costs. The indirect utility function takes a nested constant-elasticity of substitution form. This allows us to consider the choice between one aggregate non-transport good and 20 or so transport alternatives. ${ }^{9}$ The inclusion of the non-transport good allows total demand for transport to vary. The transport alternatives are combinations of mode, time of day and type of vehicle used, as shown in the utility tree in Figure 2.

\footnotetext{
${ }^{8}$ This aggregate speed-flow relationship can be derived from a detailed network model (see 0’Mahony et al., 1997)

${ }^{9}$ Labour supply is kept fixed in the model as well as the total volume of production and the product price of general consumption goods Endogenising these variables would lead to a full general
} 
The choices of the representative consumer are driven by generalized prices. Through the time-component of these generalized prices, the effect of congestion on travel time and modal choice is taken into account. The generalised costs for public transport depend on the frequency of service, allowing us to take into account the Mohring effect (Mohring 1972).

The demand for freight transport services is modelled by assuming that each firm minimises its total production cost for a given output level. It can choose between non-transport inputs (labour, capital, other intermediate goods) and a wide range of transport inputs (different modes, times of day etc.). The behaviour of the firms is represented by a nested CES cost function that is defined over generalised costs, again taking account of traffic congestion. In a typical case study, a choice can be made between peak and off-peak freight, and in both periods different modes (rail, road, inland waterways) are available. Road freight can make use of light-duty and heavyduty trucks.

\subsection{Transport supply}

The supply side of the model is simple. Supply is represented by cost functions. In each transport market, marginal resource costs of inputs other than time are constant per vehicle-kilometre, but the marginal costs may differ across transport markets (i.e. across modes, time periods, vehicle types, etc.). In passenger car and lorry markets there are no fixed costs ${ }^{10}$ and all inputs are supplied at the marginal resource cost plus tax. For collective transport markets we use a linear cost function. The constant term represents the fixed costs (e.g. administration costs, storage facilities, non-vehicle network costs). The variable term represents the rental costs of carriages and busses,

equilibrium model. However, there is a trade-off here between the detail in the modeling of the transport sector and the coverage of the whole economy.

${ }^{10}$ In line with the medium run horizon of the model, car ownership costs are expressed on a per vehicle-kilometre basis. 
as well as the costs of fuel and drivers. We assume a constant occupancy rate (different for peak and off-peak) so that we can define a marginal resource cost per passenger kilometre. The frequency of service is taken to adapt in function of the total demand for public transport, so that the waiting time is variable. Finally, the policy maker can affect environmental and other vehicle characteristics through regulations that affect the resource costs of vehicles.

For the non-transport market, the producer prices equal the constant marginal resource cost plus tax.

\subsection{Calibraton and Operation of the model}

The model is calibrated to observed or forecasted transport volumes, prices and speeds in a given region. The model is completed by a speed flow relationship (that is best derived from experiments with a network model) and by resource cost and external cost functions for all transport modes. We select elasticities of substitution for the nested utility and cost functions so as to obtain price elasticities in line with the values reported in the literature.

In simulation mode, the calibrated model computes the equilibrium for all the transport markets and for the non-transport commodity market, given a set of policy parameters (taxes, regulations on type of vehicles etc.). The equilibrium is characterised by a set of speeds, volumes and generalised costs such that no transport user wants to alter his choice. For this equilibrium the model computes external costs (air pollution, congestion, accidents, noise etc.) and a welfare indicator. The welfare indicator can loosely be described as ${ }^{11}$ the sum of total consumer surplus on the transport markets, producer surplus (the negative of the total production costs of firms

\footnotetext{
${ }^{11}$ The welfare indicator in fact equals the sum of the indirect utility levels of the representative individuals who receive all profits in all firms as well as all net tax revenue, less the external costs other than congestion. This measure is more consistent than a simple sum of consumer surpluses on markets.
} 
and the deficit or surplus of the public transport firms) and total net tax revenue, minus external costs other than congestion (congestion is included in the consumer surplus defined over generalised prices).

We can also use the model in optimization mode, by maximizing the welfare indicator under pricing constraints that represent the allowed pricing instruments. Only if there are no constraints on the tax differentiation over different markets will the derived optimum correspond to marginal social cost pricing. In most applications one is forced to compute second best optima. It is well known that this can be numerically difficult and can generate counter-intuitive results. When every pricing solution is multi-dimensional (e.g., taxes for twenty transport markets), the best constrained solution can not be found using an ad hoc search procedure The standard version of TRENEN contains no (balanced) budget requirement in any transport market or in any combination of transport markets. Instead, changes in tax revenues as caused by changes in transport policy are valued exogenously, and the exogenous value reflects an assumption on revenue use. For the purposes of this chapter, tax revenues get the same weight as consumer income. In this chapter, the optimization model will be used to compute the marginal social cost pricing solution (no constraint on tax instruments), the Ramsey pricing solution (the total tax revenue of the transport sector is constrained so that taxes in the transport sector have to be adjusted away from the MSC value) and the average cost pricing solution. In the latter solution all taxes will be constrained to equal the average resource cost. Remember that average cost is itself not constant so this is not a straightforward computation. 


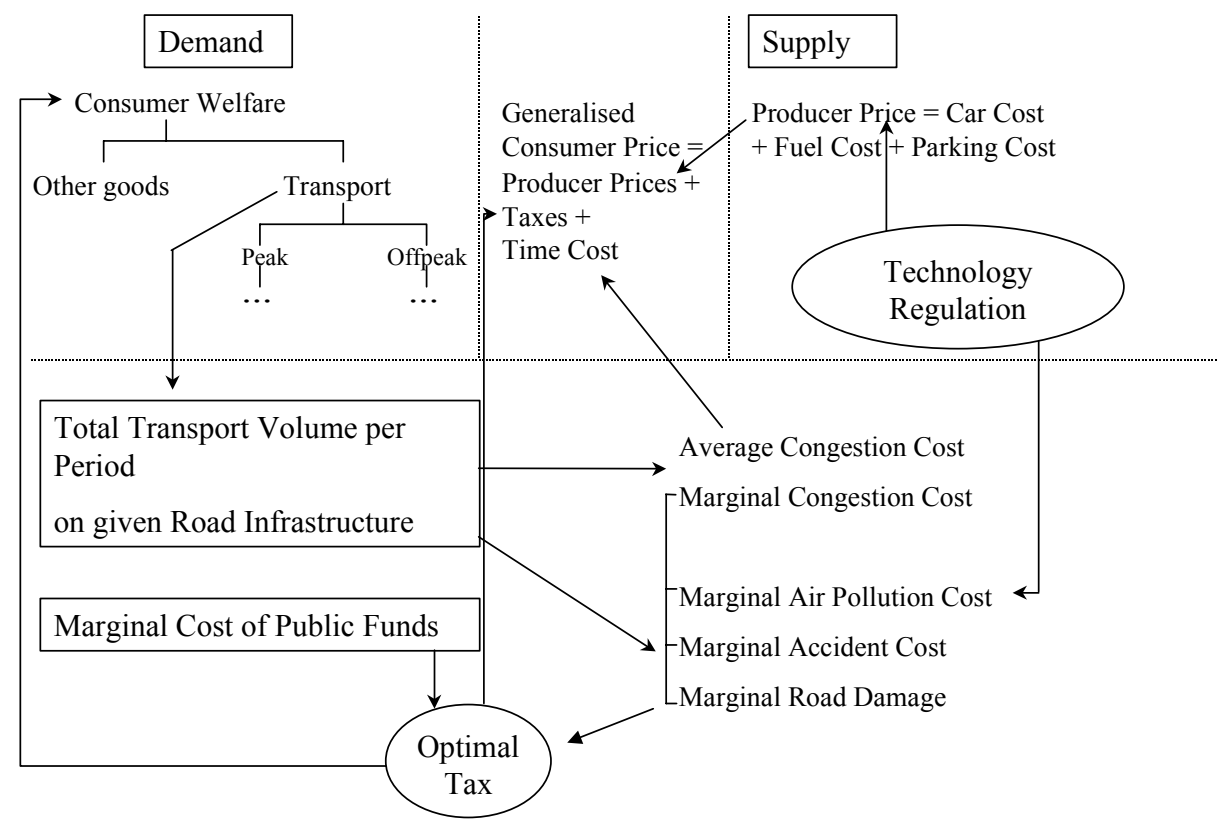

Figure 1 Model structure

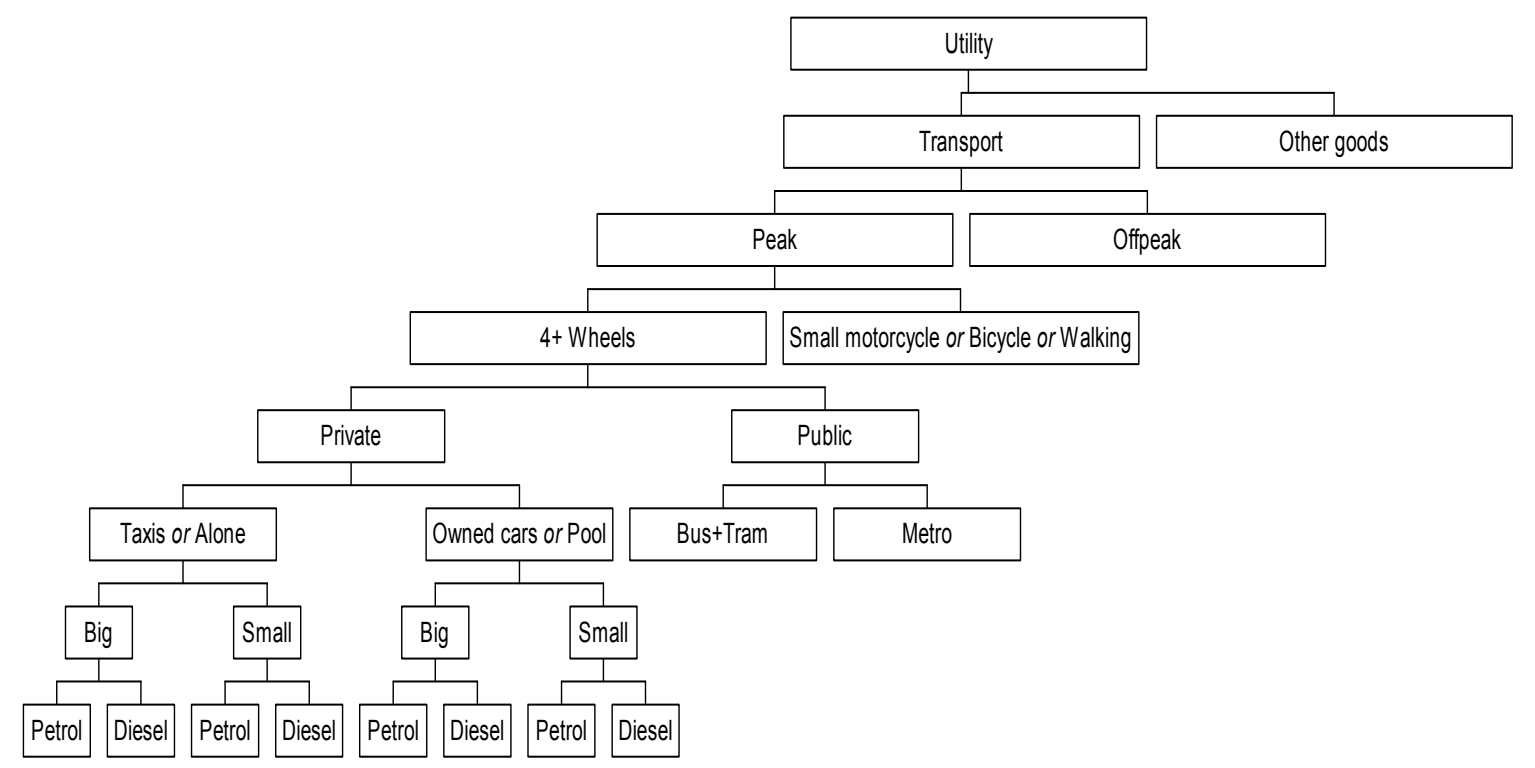

Figure 2 The nested utility tree for the behaviour of urban households (only the peak branch is shown) 


\section{AVERAGE COST POLICY SCENARIOS AND THE REFERENCE EQUILIBRIA}

\subsection{Construction of the policy scenarios}

The data used for calibrating the models were originally collected for a study on the public revenue effects of optimal pricing (Roy, 2000). That study collected data sets for different countries, including traffic flows, prices, taxes and marginal external costs.

The first step in the construction of a policy scenario for ACM and RMS is to determine the revenues that need to be raised through transport taxes. Our data sets for Germany and the UK provide information on the cost side for collective transport modes and include: urban metro, tram and bus, and non-urban bus and train, for 1995 and 2005. This information is sufficient to determine the revenue requirements for those modes, excluding road network costs.

Information on road network costs is harder collect. We made an estimate on the basis of Link and Suter (2001) and analogous assumptions are made for the UK. The values derived for total road infrastructure costs are very uncertain, but they are not crucial for the results.

Once the revenue requirements are determined, the scenarios can be designed. They are shown on Table 2 . 
Table 2: $\quad$ Policy Scenarios

\begin{tabular}{|l|l|}
\hline Scenario & Details \\
\hline The reference equilibrium (REF) & $\begin{array}{l}\text { This scenario uses the expected reference } \\
\text { prices for } 2005 \text { in all transport markets. It } \\
\text { serves as the benchmark to which the } \\
\text { remaining scenarios are compared. }\end{array}$ \\
\hline Average cost pricing (ACM) & $\begin{array}{l}\text { Here the modal budget is financed by a } \\
\text { uniform tax per vehicle kilometre for the } \\
\text { private modes and by uniform tax per } \\
\text { passenger kilometre or ton kilometre for } \\
\text { all public transport modes }\end{array}$ \\
\hline Ramsey social pricing (RMS) & $\begin{array}{l}\text { The transport-sector-wide budget of total } \\
\text { costs is financed through Ramsey taxes, } \\
\text { allowing full differentiation across } \\
\text { transport markets. The taxes maximise } \\
\text { social welfare subject to the budget } \\
\text { constraint. The social welfare function } \\
\text { takes all external costs into account, so } \\
\text { that optimal prices will be optimal } \\
\text { deviations of marginal costs, where } \\
\text { deviations are necessary to meet the } \\
\text { revenue requirements. }\end{array}$ \\
\hline Marginal social cost pricing (MSC). & $\begin{array}{l}\text { This is the theoretical optimum obtained } \\
\text { by maximisation of the welfare function, } \\
\text { allowing full differentiation of taxes } \\
\text { across transport markets, without any } \\
\text { budget constraint. }\end{array}$ \\
\hline
\end{tabular}

\subsection{Taxes and Marginal External Costs in the Reference Equilibrium}

Table 3 compares the reference taxes to total marginal external costs (TMEC). These are equal to the sum of marginal congestion costs (MCC) and other marginal external costs such as pollution for small gasoline cars and diesel buses, accidents and noise (MEPD). Taxes and marginal external costs of four transport alternatives are shown in Table 3. The values correspond to a small petrol car with one driver-occupant and a representative bus at peak and off-peak times. The taxes considered include taxes on car ownership and on use of cars (fuel taxes, existing tolls, additional VAT etc.), for 
public transport the tax equals the difference between the ticket price and the marginal resource cost. A negative tax is a subsidy.

Marginal external congestion costs clearly dominate in peak periods. ${ }^{12}$ In order to assess the pricing inefficiencies we compare the per passenger kilometre total tax ("Tax" in first column) with the total marginal external costs (TMEC in second column). We see that the total marginal external costs exceed taxes in all urban areas during peak hours. It is evident from the table that current taxes more than cover the external costs in urban areas during off-peak periods and in interurban areas at all times including peak times (see Proost et al, 2002 for more evidence). We see that there also inefficiencies for the public transport modes. With one exception, public transport prices are too low in the peak and may be too high or too low in the off peak. This may illustrate the second best policy of subsidising public transport to reduce the problems in the underpriced peak car market. Policy makers often do not appreciate that the introduction of road pricing may be an opportunity to correct the public transport prices as well.

The difference between taxes and total marginal external costs is as such insufficient to compute optimal taxes. The marginal external cost (mainly the congestion cost) is a function of the volume of transportation and this is a function of the tax itself so that one tends to overstate the necessary increase in taxes when using the marginal external cost information in the reference situation as a guideline.

\footnotetext{
${ }^{12}$ Note the high estimate for marginal external congestion costs for Munster. This follows from the small geographical scope of this case, and it explains the high welfare gains from MSC-pricing.
} 
Table 3: $\quad$ Marginal External Costs and Tax Levels in the Reference Situation-

Partial Equilibrium Model (EURO/Passenger kilometre, 2005)

\begin{tabular}{|c|c|c|c|c|c|c|c|c|}
\hline & \multicolumn{4}{|c|}{ Peak car } & \multicolumn{4}{|c|}{ Off-peak car } \\
\hline & Tax & TMEC & $\mathrm{MCC}$ & MEPD & Tax & TMEC & $\mathrm{MCC}$ & MEPD \\
\hline \multicolumn{9}{|l|}{ Germany: } \\
\hline Düsseldorf & 0.097 & 0.185 & 0.171 & 0.014 & 0.088 & 0.064 & 0.051 & 0.013 \\
\hline München & 0.097 & 0.308 & 0.252 & 0.056 & 0.088 & 0.128 & 0.073 & 0.055 \\
\hline Münster & 0.097 & 0.537 & 0.523 & 0.014 & 0.088 & 0.113 & 0.100 & 0.013 \\
\hline Westphalen & 0.089 & 0.028 & 0.022 & 0.006 & 0.106 & 0.014 & 0.009 & 0.005 \\
\hline \multirow{5}{*}{$\begin{array}{l}\text { UK: } \\
\text { London } \\
\text { South-East }\end{array}$} & & & & & & & & \\
\hline & 0.118 & 0.503 & 0.447 & 0.056 & 0.108 & 0.090 & 0.035 & 0.055 \\
\hline & 0.177 & 0.021 & 0.013 & 0.008 & 0.157 & 0.009 & 0.001 & 0.008 \\
\hline & \multicolumn{4}{|c|}{ Peak bus } & \multicolumn{4}{|c|}{ Off-peak bus } \\
\hline & Tax & TMEC & $\mathrm{MCC}$ & MEPD & Tax & TMEC & $\mathrm{MCC}$ & MEPD \\
\hline \multicolumn{9}{|l|}{ Germany } \\
\hline Düsseldorf & 0.016 & 0.037 & 0.008 & 0.029 & 0.093 & 0.036 & 0.004 & 0.032 \\
\hline München & -0.040 & 0.279 & 0.016 & 0.263 & 0.060 & 0.226 & 0.006 & 0.220 \\
\hline Münster & 0.041 & 0.064 & 0.030 & 0.034 & 0.082 & 0.042 & 0.009 & 0.033 \\
\hline Westphalen & 0.067 & 0.015 & 0.002 & 0.013 & 0.104 & 0.021 & 0.002 & 0.019 \\
\hline \\
\hline London & -0.02 & 0.708 & 0.069 & 0.639 & -0.010 & 0.398 & 0.005 & 0.393 \\
\hline South-East & 0 & 0.023 & 0.002 & 0.021 & 0.003 & 0.055 & 0.001 & 0.054 \\
\hline
\end{tabular}

Legend: (all in EURO per passenger kilometre)

Tax $=$ total amount of taxes paid

$\mathrm{TMEC}=\mathrm{MCC}+\mathrm{MEPD}=$ total marginal external cost

MCC $=$ Marginal external congestion cost

MEPD= Marginal external cost other than congestion

Source: Own calculations

Note: negative taxes are subsidies (=marginal resource cost - price) 


\section{COMPARISON OF ALTERNATIVE PRICING RULES}

This section discusses the main effects of the alternative pricing rules.

\subsection{Optimal Transport Taxes in Different Pricing Schemes}

Table 4 presents an overview of the tax levels in $\operatorname{car}^{13}$ and public transport markets, for the various policy scenarios. First, compare the two pricing rules that meet the budget requirement, ACM and RMS, to the reference situation (REF). Clearly, achieving cost recovery by mode through average cost pricing (ACM) leads to substantial car tax reductions and (very) large bus tax increases in all cases. The resulting change in relative prices of private and public modes leads to an increase in the modal share of cars ( $\mathrm{cf}$. Table 5c). Combined with the small increase in peak period traffic volumes (cf. Tables $5 \mathrm{a}$ and $5 \mathrm{~b}$ ), this exacerbates congestion and other external costs. Allowing the same budget to be raised by a Ramsey-rule (RMS) avoids these problems, as it always leads to lower bus taxes relative to car taxes. In most cases, the Ramsey bus taxes are lower than the ACM bus taxes in absolute terms as well. This price differentiation shows that, even in the presence of a cost recovery rule, price differentiation under a RMS scenario may generate substantial welfare gains. Note that in the case of Münster the Ramsey rule even calls for subsidising offpeak car travel. This is an extreme case of a second-best policy geared towards reducing peak period car use. Although the TRENEN model allows for this theoretical possibility, such a pricing system may not be a realistic policy option.

Second, compare the reference situation to MSC pricing. Although the optimal taxes under marginal social cost pricing (MSC) usually are higher than the reference

\footnotetext{
${ }^{13}$ Car taxes slightly differ in the peak and off peak period even though the tax system does not distinguish between times of day. The difference is made by the TRENEN model, which takes into account the difference in fuel consumption between peak and off-peak.
} 
taxes for peak period car trips, there are exceptions, such as South-East England, which has low average congestion levels in the reference equilibrium. The impact on off-peak car taxes is more diverse: in both regions, Westphalen and South-East England, the off-peak car taxes decrease. In all cities except London, car taxes increased in comparison to the reference equilibrium. This result may be driven by the geographical scale of the case studies, as those cases covering the largest areas have decreasing off-peak taxes. Taking large networks into account may tend to spread out off-peak congestion levels. 
Table .4: $\quad$ Tax Levels for Different Pricing Scenarios, 2005

\begin{tabular}{|c|c|c|c|c|c|c|c|c|}
\hline \multirow[t]{2}{*}{ (EURO/PKM) } & \multicolumn{4}{|c|}{ Peak car } & \multicolumn{4}{|c|}{ Off-peak car } \\
\hline & REF & $\mathrm{ACM}$ & RMS & MSC & REF & $\mathrm{ACM}$ & RMS & MSC \\
\hline Germany: & & & & & & & & \\
\hline Düsseldorf & 0.097 & 0.037 & 0.239 & 0.253 & 0.088 & 0.037 & 0.089 & 0.156 \\
\hline München & 0.097 & 0.037 & 0.308 & 0.308 & 0.088 & 0.037 & 0.203 & 0.203 \\
\hline Münster & 0.097 & 0.038 & 0.090 & 0.380 & 0.088 & 0.033 & -0.070 & 0.184 \\
\hline Westphalen & 0.089 & 0.035 & 0.070 & 0.099 & 0.106 & 0.035 & 0.070 & 0.084 \\
\hline \multirow{5}{*}{$\begin{array}{l}\text { UK: } \\
\text { London } \\
\text { South-East }\end{array}$} & & & & & & & & \\
\hline & 0.118 & 0.105 & 0.589 & 1.000 & 0.108 & 0.105 & 0.505 & 0.840 \\
\hline & 0.177 & 0.060 & 0.034 & 0.114 & 0.157 & 0.060 & 0.021 & 0.100 \\
\hline & \multicolumn{4}{|c|}{ Peak bus } & \multicolumn{4}{|c|}{ Off-peak bus } \\
\hline & REF & $\mathrm{ACM}$ & RMS & $\mathrm{MSC}$ & REF & $\mathrm{ACM}$ & RMS & MSC \\
\hline \multirow{5}{*}{$\begin{array}{l}\text { Germany: } \\
\text { Düsseldorf } \\
\text { München } \\
\text { Münster } \\
\text { Westphalen }\end{array}$} & & & & & & & & \\
\hline & 0.016 & 0.311 & 0.143 & 0.104 & 0.060 & 0.522 & 0.089 & 0.104 \\
\hline & -0.040 & 0.343 & 0.382 & 0.382 & 0.060 & 0.450 & 0.349 & 0.349 \\
\hline & 0.041 & 0.100 & -0.060 & 0.041 & 0.082 & 0.146 & -0.020 & 0.082 \\
\hline & 0.067 & 0.100 & -0.040 & 0.027 & 0.104 & 0.190 & -0.030 & 0.029 \\
\hline \multirow{3}{*}{$\begin{array}{l}\text { UK: } \\
\text { London } \\
\text { South-East }\end{array}$} & & & & & & & & \\
\hline & -0.02 & 0.234 & 0.150 & 0.785 & -0.010 & 0.231 & -0.060 & 0.517 \\
\hline & 0 & 0.082 & 0.015 & 0.043 & 0.003 & 0.254 & 0.043 & 0.073 \\
\hline
\end{tabular}

Source: Own calculations

Note: PKM: Passenger-kilometre 


\subsection{Traffic Level and Composition}

Tables $5 \mathrm{a}, .5 \mathrm{~b}$ and $5 \mathrm{c}$ show the impact of the pricing mechanisms on traffic levels (passenger car units, PCU), on transport demand (passenger-kilometre, PKM), and on modal shares, respectively. Average cost pricing leads to an increase in traffic levels and transport demand, because the taxes are on average reduced with respect to the reference situation. The increase in PCU is larger than for PKM because of a modal shift towards car trips (Table 5c), away from collective modes, as a consequence of the relatively high revenue requirement (hence, relatively high taxes) for collective modes, and the relatively low revenue requirement in car markets. This illustrates that defining budget requirements in narrow sets of transport markets may have strong effects on modal split. The simple average cost pricing scheme performs badly both in terms of aggregate travel demand and in terms of modal split for a given level of demand. ${ }^{14}$

Ramsey social pricing, on the other hand, manages to combine lower PCU levels (hence less congestion) with increased transport demand in a number of cases: Düsseldorf, München, London, and to a lesser extent, the region of Westphalen. The reason is that, despite the low revenue requirements, relative modal prices can be set to achieve a good modal split. In practice this requires low or zero fares for collective modes. In other cases, such as Münster and the South-East region in the UK, the revenue requirement is too low to allow for sufficient price differentiation, and increased PCU levels result.

Marginal social cost pricing usually reduces travel demand (PKM) and traffic flows (PCU) in comparison to the reference situation, and leads to revenues in excess of the revenue requirements specified for average cost pricing and Ramsey social 
pricing. Under marginal social cost pricing there is no longer a justification for subsidising public transport beyond the level of fixed costs. ${ }^{15}$ The efficient modal split is obtained by pricing all modes at their marginal social cost.

Table 6 shows the share of trips (measured in PCUs) that take place during peak hours. As can be seen this share is less sensitive to the pricing scheme than is the total traffic volume. Ramsey social pricing performs much like marginal social cost pricing in this respect, through a second best correction of prices. The effect of average cost pricing is to slightly decrease the share of peak hour trips in most cases.

\footnotetext{
${ }^{14}$ Although not computed, it is likely that a Ramsey pricing scheme with modal budget constraints - as opposed to a sector-wide constraint - will suffer from the same problem, to a lesser - but still considerable - extent.

${ }^{15}$ The economics of density in public transport or Mohring effect is the exception. If the frequency of service increases due to additional passengers, there is a positive externality in public transport. The marginal social cost thus equals the sum of the marginal operating costs and the marginal external costs (congestion, air pollution, accidents) minus the external benefit of a more frequent service. Van Dender and Proost (2001) find that taking account of this positive externality has limited effects on the welfare potential of pricing reforms, but that it decreases fare revenues while public transport expenditures increase.
} 
Table 5a: $\quad$ Traffic Level Index (PCU) under Different Pricing Scenarios. 2005

\begin{tabular}{|l|l|l|l|l|}
\hline & REF & ACM & RMS & MSC \\
\hline Germany & 1 & 1.13 & 0.95 & 0.91 \\
\hline Düsseldorf & 1 & 1.12 & 0.97 & 0.88 \\
\hline München & 1 & 1.07 & 1.07 & 0.90 \\
\hline Münster & 1 & 1.03 & 0.99 & 0.99 \\
\hline $\begin{array}{l}\text { Westphalen } \\
\text { region }\end{array}$ & \multicolumn{5}{l|}{} \\
\hline UK & 1 & 1.06 & 0.91 & 0.76 \\
\hline London & 1 & 1.04 & 1.01 \\
\hline South east region & 1 & 1.11 & & \\
\hline
\end{tabular}

Source: Own calculations 
Table 5b: $\quad$ Transport Demand Index (PKM) under Different Pricing Scenarios, 2005

\begin{tabular}{|c|c|c|c|c|}
\hline & REF & $\mathrm{ACM}$ & RMS & MSC \\
\hline \multicolumn{5}{|l|}{ Germany } \\
\hline Düsseldorf & 1 & 1.05 & 1.04 & 0.92 \\
\hline München & 1 & 1.05 & 1.03 & 0.94 \\
\hline Münster & 1 & 1.03 & 1.10 & 0.95 \\
\hline $\begin{array}{l}\text { Westphalen } \\
\text { region }\end{array}$ & 1 & 0.98 & 1.08 & 1.01 \\
\hline \multicolumn{5}{|l|}{ UK } \\
\hline London & 1 & 1.03 & 1.11 & 0.88 \\
\hline South east region & 1 & 0.96 & 1.03 & 1.00 \\
\hline
\end{tabular}

Source: Own calculations

Table 5c: Modal Share of Car in Peak and Off-Peak (\%) under Different Pricing Scenarios, 2005

\begin{tabular}{|l|l|l|l|l|l|l|l|l|}
\hline & \multicolumn{4}{|l|}{ Peak car share } & \multicolumn{4}{l|}{ Off-peak car share } \\
\hline & REF & ACM & RMS & MSC & REF & ACM & RMS & MSC \\
\hline Germany: & & & & & & & & \\
Düsseldorf & 67.1 & 76.0 & 65.7 & 65.8 & 66.1 & 82.4 & 62.4 & 62.5 \\
München & 71.2 & 76.7 & 68.2 & 69.0 & 70.3 & 78.3 & 67.1 & 92.1 \\
Münster & 84.0 & 86.3 & 83.7 & 80.0 & 84.2 & 89.1 & 88.6 & 81.4 \\
& 85.7 & 89.4 & 78.3 & 85.0 & 85.7 & 90.9 & 77.8 & 83.2 \\
Westphalen & & & & & & & & \\
\hline UK: & & & & & & & & \\
London & 53.4 & 55.0 & 46.3 & 45.9 & 69.9 & 74.9 & 62.4 & 57.9 \\
South-East & 70.1 & 81.1 & 74.7 & 74.7 & 77.0 & 91.5 & 76.6 & 76.4 \\
\hline
\end{tabular}

Source: Own calculations 
In the urban case studies, the impact of the different pricing schemes on freight transport is small, and the directions of change are similar to those of passenger car transport. In regional contexts, average cost pricing decreases the modal share of rail freight, in comparison to the reference situation. Ramsey social pricing does the opposite: it strongly pushes the share of rail up. In the Westphalen case, Ramsey social pricing leads to a much higher share of rail freight than in the marginal social cost pricing scenario. In the South-East UK case, the Ramsey share is approximately equal to the marginal social cost pricing share. Overall, the impact of the various schemes on aggregate freight demand is rather small. 
Table 6: $\quad$ Share of Peak Period PCU, 2005

\begin{tabular}{|l|l|l|l|l|}
\hline & \% under REF & \% under ACM & \% under RMS & \% underMSC \\
\hline Germany & & & & \\
\hline Düsseldorf & 63.3 & 61.0 & 62.1 & 62.2 \\
\hline München & 58.7 & 56.9 & 57.5 & 58.0 \\
\hline Münster & 59.1 & 58.3 & 55.0 & 56.5 \\
\hline Westphalen region & 64.0 & 64.0 & 63.7 & 63.3 \\
\hline UK & & & & \\
\hline London & 68.1 & 66.9 & 68.0 & 69.1 \\
\hline South east region & 69.5 & 69.8 & 69.3 & 69.3 \\
\hline
\end{tabular}




\subsection{Welfare Impacts}

Table 7 shows the welfare changes induced by the different pricing scenarios for the various cases. These welfare changes are expressed as a percentage of total generalized income and this is larger than national income. A welfare gain of $1 \%$ of generalized income realized on the transport market that only counts for $10 \%$ or less of total national income is therefore to be considered as important. Of course, marginal social cost pricing outperforms Ramsey social cost pricing, which in turn outperforms average cost pricing. First, the introduction of a budget constraint has a clear efficiency cost for the transport sector. Second, the way in which this constraint is met has further consequences for the welfare effects. Ramsey social pricing cannot be worse than average cost pricing and cannot be better than marginal social cost pricing.

Interestingly, average cost pricing leads to a reduction of welfare with respect to the reference situation in all cases. While the size of the reduction varies substantially between cases, the two basic reasons for the welfare reductions are the same. 
Table.7: Welfare Impacts of Pricing Scenarios, \% change with respect to REF, 2005)

\begin{tabular}{|l|l|l|l|l|}
\hline & REF & ACM & RMS & MSC \\
\hline Germany & 0 & -0.79 & +0.09 & +0.14 \\
\hline Düsseldorf & 0 & -0.61 & +0.14 & +0.41 \\
\hline München & 0 & -2.45 & -2.15 & +2.45 \\
\hline Münster & 0 & -0.17 & -0.06 & +0.09 \\
\hline $\begin{array}{l}\text { Westphalen } \\
\text { region }\end{array}$ & \multicolumn{5}{l|}{} \\
\hline UK & 0 & -0.76 & +1.28 & +2.70 \\
\hline London & 0 & -1.89 & +0.18 & +0.55 \\
\hline South east region & 0 &
\end{tabular}

Source: Own calculations 
First, the current transport prices go some way towards a second-best pricing structure. Under-priced passenger car transport (from the social point of view) is often combined with subsidised public transport, so that relative price distortions are reduced. Such a policy is not feasible under the modal budget requirements used in the average cost pricing simulations. Taxes for each mode are only determined by the modal revenue requirement, so that no account can be taken of prices in substitute modes.

Second, the modal budget constraints require less revenue than is raised in the reference situation. This means that the revenues from current transport taxes are higher than what is required to balance the transport sector financially. Optimal commodity tax theory shows that, if transport demand is relatively inelastic, revenueraising in that sector tends to limit the efficiency cost of collecting the required total amount of government revenue. ${ }^{16}$ The fact that the transport sector at present is 'revenue positive' may then be justified from the optimal taxation point of view, although there is no guarantee that relative prices or the size of the surplus are anywhere near optimal.

If the revenue requirement were increased above the transport-related requirement, average cost pricing could, but need not, perform better than the reference price structure. As the peak-period taxes from average cost pricing approach the peak period external costs, the performance of ACM improves. This improvement will be counteracted to some extent by the growing deviation between off-peak taxes and off-peak external costs. ${ }^{17}$ However, since peak-period congestion costs are the

\footnotetext{
${ }^{16}$ The potential interactions with other distorted markets such as the labour market are ignored in this study; cf. Mayeres and Proost (1997), Parry and Bento (2001) and Van Dender (2003) for analyses of this issue.

${ }^{17}$ Sensitivity analysis for the Düsseldorf case shows that increasing the revenue requirement to $150 \%$ of the central case actually decreases the performance of $\mathrm{AC}$ in terms of welfare.

Decreasing the revenue requirement to $50 \%$ of the central scenario improves the performance
} 
dominant externality, a net improvement of welfare should be expected. Ramsey social pricing is better or worse than the reference situation depending on the case considered. The problem of reducing the amount of revenue to be raised, as compared to the reference situation, is less prominent here, as price differentiation is still possible. Second-best relative price structures are still a feasible policy option. It should be noted however that Ramsey social pricing performs considerably worse than marginal social cost pricing in all cases. This result suggests that the level of the revenue requirement is an important co-determinant of the welfare effects of transport pricing policies. Raising no more revenue than the one required for infrastructure financing (keeping the level of road infrastructure constant) may strongly reduce the welfare potential of pricing policies aimed at internalising externalities.

The variation in results between cases depends on the degree of cost coverage of collective modes in the reference situation, and on the degree to which the new budget constraint allows sufficient differentiation of prices with respect to transport externalities. The high welfare gains for Munster have to do with the very steep speed flow relationship in the reference equilibrium. This implies that small reductions in volumes in the peak can generate important increases in speed and in welfare for the local population.

\section{CONCLUSIONS}

In this paper we analysed the potential of more efficient pricing for the transport sector as a whole and the impact of budget constraints.

of AC. These however, are not general results. In a second sensitivity analysis, the budgets were linked to changes in traffic levels. At the central scenario revenue requirement, this decreases the performance of AC. At $50 \%$ of the central scenario requirement, this link increases the performance of AC. The relation between changes in the budget requirement and the performance of $\mathrm{AC}$ is clearly non-monotonous. Interactions between budgets, the 
Implementing marginal social cost pricing without budget constraints generates in principle the highest welfare gains. This pricing reform requires important changes for for the road sector (road pricing etc.) but also for the public transport modes where in many regions peak tariffs need to be increased. Overall mobility needs to decrease by 5 to $10 \%$ and modal shares of cars will go down in the peak.

We studied to extreme scenarios to add a balanced budget constraint to the overall transport pricing reform. The first is simple average cost pricing per mode. The second is Ramsey pricing with a budget constraint for the transport sector as a whole. The comparison of transport pricing approaches shows that Ramsey-type pricing rules perform significantly better in terms of welfare than average cost based rules, and that the absence of a modal budget constraint allows to better adapt prices to marginal social cost.

The case studies suggest that the quantitative effects may be important. Requiring that modal budgets are met exactly through average cost pricing reduces welfare in comparison to the reference situation, in all cases studied by 0.5 to more than $2.5 \%$ of national income. When the budget constraint is attained through Ramsey taxes, the results are most often welfare improving compared to the reference. The welfare cost of imposing the budget constraint, however, remains substantial in comparison to a marginal social cost pricing scheme.

These results as such say nothing about the political and social feasibility of the various pricing rules. Furthermore, there are other ways of defining average cost pricing schemes than the ones analysed here, and such alternative definitions may produce better results. These alternative schemes will however become more requirement, may produce counterintuitive results. 
complex, and they will still perform worse than marginal-cost-based pricing approaches.

\section{ACKNOWLEDGEMENTS}

Support from the European Commission under the Fifth Transport Resarch and Technology Framework Program is gratefully acknowledged. We benefited from the comments on earlier versions by the editor of this volume, by two anonymous referees and by Inge Mayeres.

\section{REFERENCES}

De Borger, B. (2001). Discrete Choice Models and Optimal Two-Part Tariffs in the Presence of Externalities: Optimal Taxation of Cars, Regional Science and Urban Economics, 31, 4, 471-504.

De Borger, B. and S. Proost (Eds.) (2001). Reforming Transport Pricing in the European Union, A Modelling Approach. Edward Elgar: Cheltenham Northampton

Glaister, S. and D. Lewis (1978). An Integrated Fares Policy for Transport in London, Journal of Public Economics, 9, 341-355

Grossman, G. and E. Helpman (2001). Special Interest Politics, MIT Press, Cambridge - London

Jha, R. (1998). Modern Public Economics. Routledge, London - New York

Laffont, J. and J. Tirole (1993). A Theory of Incentives in Procurement and Regulation, MIT Press, Cambridge - London

Link, H., H.L. Stewart, C. Doll, P. Bickel, S. Schmid, R. Friedrich, S. Suter, H. Sommer, M. Marti, M. Maibach, C. Schreyer and M. Peter. (2001). Pilot Account 
Results for Germany and Switzerland. UNITE (UNIfication of accounts and marginal costs for Transport Efficiency) Deliverable 5 Funded by 5th Framework RTD Programme, ITS, University of Leeds, Leeds.

http://www.its.leeds.ac.uk/projects/unite/D5.pdf

Link, H. and S. Suter (2001). Summary of the German and Swiss Pilot AccountsBackground paper - Draft version, UNITE Deliverable 5, mimeo, presented at Ecole Nationale des Ponts et Chaussées, Paris, 17-18 September 2001

Link, H., L. Stewart, M. Maibach, T. Sansom and Nellthorp, J. (2000). The Accounts Approach. UNITE Deliverable 2. Funded by the 5th Framework RTD Programme. ITS, University of Leeds, Leeds. http://www.its.leeds.ac.uk/projects/unite/D2.pdf Mayeres, I. and S. Proost (1997). Optimal Tax and Public Investment Rules for Congestion Type of Externalities, Scandinavian Journal of Economics, 99, 261279

Mayeres, I. and S. Proost (2003). Reforming Transport Pricing: An Economist's Perspective on Equity, Efficiency and Acceptability, in J.Schade, B.Schlag (eds.), Acceptability of transport pricing strategies, Elsevier, Oxford

Mohring, H. (1972), Optimization and Scale Economies in Urban Bus Transportation, American Economic Review, 591-604

Newbery, D. and G. Santos (1999). Road Taxes, Road User Charges and Earmarking, Fiscal Studies, 20, 2, 103-132

O’Mahony, M., K. Kirwan and S. McGrath (1997). Modelling the Internalisation of External Costs of Transport, Transportation Research Record 1576, 93-98

Pindyck, R. and D. Rubinfeld (2001). Microeconomics, Fifth Edition, Prentice Hall, New Jersey 
Parry, I. and A. Bento (2001). Revenue Recycling and the Welfare Effects of Road Pricing, Scandinavian Journal of Economics, 103, 645-671

Proost, S. and K. Van Dender (2001a). The Welfare Impacts of Alternative Policies to Address Atmospheric Pollution in Urban Road Transport, Regional Science and Urban Economics, 31, 4, 383-412.

Proost, S. and K. Van Dender (2001b). Methodology and Structure of the Urban Model, in: B. De Borger and S. Proost (Eds.), Reforming Transport Pricing in The European Union: A Modelling approach, Edward Elgar, Cheltenham Northampton, 65 - 92

Proost, S., K. Van Dender, C. Courcelle, B. De Borger, J. Peirson, D. Sharp, R. Vickerman, E. gibbons, M O’Mahony, Q. Heany, J. van den Bergh and E. Verhoef (2002). How large is the gap between present and efficient transport prices in Europe?, Transport Policy, 9, 1, 41-57.

Roy, R. (Ed.) (2000). Revenues from Efficient Pricing: Evidence from the Member States, UIC/CER/European Commission DG-TREN Study

Tirole, J. (1994). The internal organization of government, Oxford Economic Papers, 46, p.1-29

Van Dender, K. (2003.) Transport Taxes with Multiple Trip Purposes, Scandinavian Journal of Economics, 105, 2, 295-310

Van Dender, K. and S. Proost (2001). Optimal Urban Transport Pricing with Congestion and Economies of Density, ETE Working Paper 2001-19 http://www.econ.kuleuven.ac.be/ew/academic/energmil/publications/default.htm 
The Center for Economic Studies (CES) is the research division of the Department of Economics of the Katholieke Universiteit Leuven. The CES research department employs some 100 people. The division Energy, Transport \& Environment (ETE) currently consists of about 15 full time researchers. The general aim of ETE is to apply state of the art economic theory to current policy issues at the Flemish, Belgian and European level. An important asset of ETE is its extensive portfolio of numerical partial and general equilibrium models for the assessment of transport, energy and environmental policies.

\section{ETE WORKING PAPER SERIES 2003}

$n^{\circ} 2003-11$

$n^{\circ} 2003-10$

$n^{\circ} 2003-09$

$n^{\circ} 2003-08$

$n^{\circ} 2003-07$

$n^{\circ} 2003-06$

$n^{\circ} 2003-05$

$n^{\circ} 2003-04$

$n^{\circ} 2003-03$

$n^{\circ} 2003-02$

$n^{\circ} 2003-01$
Proost S. And Van Dender K. (2003), Marginal Social Cost Pricing For All Transport Modes And The Effects Of Modal Budget Constraints

Mayeres I., Van Regemorter D. (2003), Modelling the health related benefits of environmental policies - a CGE ANALYSIS for the EU countries with GEM-E3

De Borger B., Proost S., Van Dender K. (2003), Congestion And Tax Competition In A Parallel Network

Pepermans G., Driesen J., Haeseldonckx D., D'haeseleer W. and Belmans R. (2003), Distributed generation: definition, benefits and issues

Moons E., The development and application of economic valuation techniques and their use in environmental policy - A survey

Muys B., Deckmyn G., Moons E., Quijano J.G., Proost S. and Ceulemans R. (2003), An integrated decision support tool for the prediction and evaluation of efficiency, environmental impact and total social cost of forestry projects in the framework of the Kyoto protocol

Proost, S. and Van Regemorter, D. (2003), Climate change policy in European countries and its effects on industry

Willems, B. (2003), Should an incumbent generator be allowed to buy import transmission capacity?

Rousseau, S. and Billiet, C.M. (2003), Using emission standards under incomplete compliance

Calthrop, E., De Borger, B. and Proost S. (2003), Tax reform for dirty intermediate goods: theory and an application to the taxation of freight transport

Pepermans, G. (2003), Simulating the restructuring of the Flemish electricity distribution sector

\section{ETE WORKING PAPER SERIES 2002}

Willems, B. (2002), Barring consumers from the electricity network might improve welfare 